\title{
Extirpolation of the Mythology That Porotic Hyperostosis Is Caused by Iron Deficiency Secondary to Dietary Shift to Maize
}

\author{
Bruce Rothschild ${ }^{1,2,3}$ \\ ${ }^{1}$ Biodiversity Institute, University of Kansas, Lawrence, USA \\ ${ }^{2}$ Anthropology Department, University of Kansas, Lawrence, USA \\ ${ }^{3}$ Department of Medicine, Northeast Ohio Medical University, Rootstown, USA \\ Email: bmr@ku.edu
}

Received May $18^{\text {th }}$, 2012; revised June 20 ${ }^{\text {th }}$, 2012; accepted July $6^{\text {th }}, 2012$

\begin{abstract}
Diagnosing a shift to a maize-dominant diet, on the basis of recognition of high population frequencies of porotic hyperostosis, has unfortunately entered the "collective consciousness" of anthropology-because of the mythology that iron deficiency is a common cause of that phenomenon. Skull changes in patients with all forms (both primary and secondary) of iron deficiency are actually extremely rare $(0.68 \%$ !). That frequency certainly does not support iron deficiency as the explanation for the high frequency of porotic hyperostosis noted (approximating 50\%) in some populations. Isotopic analysis further reveals that $\mathrm{C}_{4}$ grasses (e.g., maize) actually did not become a significant part of North American human diets until the past 1000 years, long after notation of high frequency porotic hyperostosis. This further falsifies claims of earlier maize diets (predicated on frequency of porotic hyperostosis) and negates the perception that maize-induced iron deficiency is the cause of porotic hyperostosis. The latter speculation is not only contrary to medical evidence, but that misdirection gave false impressions of ancient populations/civilizations and compromised use of a valuable observation. That mythology must be extirpated from the "collective consciousness". Perhaps now attention can be appropriately directed to exploration of genetic hemolytic anemia, hemoglobinopathies and parasitic infestations which are known causes of porotic hyperostosis.
\end{abstract}

Keywords: Iron Deficiency; Porotic Hyperostosis; Cribra Orbitalia; Maize; Diet; Parasite; Hemolytic Anemia; Mythology

\section{The Importance of Scientific Methodology}

This editorial makes recommendation for deletion of the mythology that maize consumption is the dietary implication of porotic hyperostosis. The term mythology is used herein to describe perspectives attributed to authority, but which are contrary to the scientific evidence. The mythology (that primary iron deficiency is the cause of porotic hyperostosis) appears embedded in anthropology's "collective consciousness" (Angel, 1978; El-Najjar et al., 1975; Grmek, 1989; Hill \& Armelagos, 1990; Von Endt \& Ortner, 1982). This persistence needs to be reexamined in view of the observations by Claude Bernard and Will Rogers that it is not what we don't know that gets us into trouble, so much as what we know that ain't so (Spodick, 1975). When one's life work is predicated on a perspective/technique, it takes tremendous intellectual integrity to accept that the premise for that life's work was fatally flawed in a manner that renders it moot, thus negating a large portion of his/her past intellectual efforts. I am impressed by medical colleagues who had the integrity to accept an article documenting the failure of standard radiological examination to distinguish sacroiliac pathology, an article which invalidated literally thousands of articles which utilized the x-ray to identify study groups (Rothschild et al., 1994). The reviewers understood that falsifying the underlying premise for such work was what science does and that it did not reflect negatively on the reporters of past work. Failing to accept documentation/evidence would have been contrary to the fundamental premise of scientific study, despite the new information rendering moot so many previous studies. The reviewers cared more for the integrity of science than for the perceived value of their own contributions (based upon the now falsified data) and by doing so actually enhanced their own reputations as scientists. For researchers without a "personal stake" in an issue, replacing authoritative statements with data-based statements is mindful of the child's comment related to "the emperor's new clothes". While "elders" should be respected, it is unclear that their pronouncements should be blindly followed?

\section{Misconceptions}

\section{Primary Iron Deficiency Does Not Cause Porotic Hyperostosis}

Relating porotic hyperostosis to primary iron deficiency is contrary to the medical evidence: The radiological (medically recognized) equivalent of porotic hyperostosis is the "hair on end" or "crew cut" phenomenon (Resnick, 2002). Porotic hyperostosis is the result of marrow hyperplasia (Resnick, 2002), a process that increases consumption of basic nutrients, especially iron (Fairbanks \& Beutler, 1972). Iron deficiency is the result, not the cause of the marrow hyperplasia that produces the porotic hyperostosis. This contrasts with primary iron deficiency, which causes hypo-regenerative (atrophic) marrow and no skull alterations (Fairbanks \& Beutler, 1972).

What then are the observations that have been misinterpreted as suggesting that primary iron deficiency causes porotic hyperostosis at population frequencies approaching 50\% (Angel, 
1978; El-Najjar et al., 1975)? I have no idea and can identify nothing in the literature that documents (rather than simply espouses) the misconception/mythology of a relationship to porotic hyperostosis!

Examining the medical literature on iron deficiency-related skeletal phenomena is most illuminating. Iron deficiency is an extremely common affliction among patients admitted to the Cape Town and Red Cross War Memorial Children's Hospital in South Africa. Yet Lanzkowsky (1968) could identify only 15 cases among the thousands identified and found no relationship to severity of the iron deficiency. Even the diagnosis of primary iron deficiency is questioned in those cases (see comments below on secondary iron deficiency related to parasitism and hemoglobinopathies). Agarwal et al. (1970) revealed a frequency of porotic hyperostosis-relatable skull changes in only $0.68 \%$ of individuals with iron deficiency and no atrophy of parietal bones! Only 16 cases of skull changes were added to the literature (from among thousands of individuals with iron deficiency) in the ensuing years (Rothschild, 2000), certainly an insufficient number upon which to base frequent occurrence of porotic hyperostosis. Eng (1958) documented that the iron deficiency was the result of another process, even when those rare skull changes happened to occur in individuals with iron deficiency. Interestingly, Agarwal et al. (1970) noted a significant frequency of frontal bone thinning, with only occasional parietal bone thinning in his population study of iron deficiency. This differs from porotic hyperostosis in two fundamental aspects. It was the frontal bone that was affected in their study, as contrasted with predominantly parietal involvement in porotic hyperostosis. Further, they described cortical thinning and no thickening of the diploic space, which contrast with the thickening characteristic of porotic hyperostosis.

The intellectual challenge promulgating the mythology appears related to failure to recognize that iron deficiency can be caused not only by inadequate ingestion but by processes that increase its utilization. Any process which causes marrow hyperplasia increases consumption of basic nutrients (Fairbanks \& Beutler, 1972). The result is a secondary deficiency of those nutrients. Hyperplasia is the physiologic response of bone marrow to any phenomenon which consumes red blood cells, processes which increase red blood cell fragility or those that reduce the ability of red blood cell hemoglobin to carry and transfer oxygen. Certain abnormalities of hemoglobin production result in only partially or non-functioning molecules. Thus, nutrients (especially iron) are consumed, but the hematologic deficiency "(anemia) persists, stimulating more consumption, but not resolving the stimulus (e.g., anemia). The process is referred to as ineffective erythropoiesis. One such genetic disorder causing hemolytic anemia is thalassemia major, a known cause of the "hair on end" phenomenon recognized as porotic hyperostosis (Caffey, 1957; Resnick, 2002). Such afflicted individuals may become deficient of usable iron stores (Fairbanks \& Beutler, 1972), but that is the result, not the cause of the process producing the skull changes. This is in contrast to other hemoglobin abnormalities (e.g., sickle cell anemia) which cause damage by physically blocking circulation, but are neither associated with ineffective erythropoiesis, nor with porotic hyperostosis.

Oxenham and Cavill (2010) suggest that iron deficiency produces ineffective erythropoiesis, self-citing a review (Cavil 2002), which itself cites his own chapter (Cavill \& Ricketts, 1980), but unfortunately provide no primary reference evidence to support their claim. As these publications do not present actual data (only opinion) and do not address the above-referenced radiological evidence, they do not seem to have any pertinence to the question.

\section{Analysis of Skull Pathology}

\section{What Is the Cause of Skull Changes, although Rare, in Individuals with Iron Deficiency?}

Lanzkowsky (1968) identified hemolytic anemias (on the basis of shortening of the intravascular life span of red blood cells) in 8 of 14 individuals with iron deficiency. Red blood cell half-life is not shortened in primary iron deficiency anemia (Kaplan \& Zuelzer, 1950; Temperley \& Sharp, 1962). The other six individuals also had rickets, a disorder that Silverman (1985) documented and that Lanzkowsky (1968) emphasized can cause these same skull changes. Eng's (1958) report of iron deficiency related skull changes was in an individual with peripheral blood spherocytes and splenomegaly, a disorder referred to as spheroscytosis and a recognized cause of hemolytic anemia (Young et al., 1951). Thus, the thought that primary iron deficiency causes porotic hyperostosis "has no clothes". Porotic hyperostosis in individuals who happen to be iron deficient cannot be blamed on that deficiency.

\section{Cribra Orbitalia Is a Separate Phenomenon from Porotic Hyperostosis}

Porotic hyperostosis and cribra orbitalia are independent phenomena, both on an intra- and inter-population basis. A team of senior investigators (Rothschild et al., 2005) even documented an inverse relationship between cribra orbitalia and porotic hyperostosis in skulls from the Wedda of Sri Lanka and from geographically and other chronologically disparate sites, including Bonnell, Pindi Pueblo, McCutchan-McLaughlin, Lake Bronson, Warner Mound, Peter Lee Mound, Blue Blanket Point Altern, Morrison's Island, Greenville and Seh Gabi. It is quite clear that cribra orbitalia and porotic hyperostosis could not represent the same phenomenon. Therefore, the topic of cribra orbitalia, which clearly has a variety of forms and likely causes (Rothschild \& Martin, 2006), is beyond the scope of the current issue.

\section{What then Is the Significance of Porotic Hyperostosis?}

To what potential condition(s) does the presence of porotic hyperostosis actually provide insight? The clinical literature provides a possible explanation. Accentuated bone marrow red cell production is the source of porotic hyperostosis (Goodhart \& Shils, 1982; Jaffe, 1972; Resnick, 2002; Rothschild \& Martin, 2006). What causes increased red cell production? Blood loss or red blood cell destruction are the processes that have been identified. The former complicates some parasitic infections; the latter, caused by hemolytic anemia. Enzyme deficiencies (e.g., pyruvate kinase and glucose-6-phosphate dehydrogenase abnormalities reducing function), abnormal red cell membranes (e.g., hereditary spherocytosis) increasing red blood cell fragility and hemoglobinopathies (e.g., thalassemia and sickle cell anemia) are the most common causes for the latter (Resnick, 2002; Rothschild \& Martin, 2006). Hemoglobinopathies (though sickle cell only rarely) are characterized by ineffective ery- 
thropoiesis (Caffey, 1957; Resnick, 2002). Afflicted individuals may become deficient of usable iron stores (Fairbanks \& Beutler, 1972), developing a secondary iron deficiency-after the marrow hyperplasia has consumed the iron.

Hemolytic anemia is well recognized in the Old World, especially that related to fava bean ingestion among individuals with the "inborn error of metabolism," glucose-6-phosphate dehydrogenase deficiency (Grmek, 1989; Kattamis et al., 1969). Parasitic infections/infestations are especially important to consider in New World populations. Although they generally produce direct blood loss from the host (e.g., from Ancyclostoma), some (e.g., the fish tapeworm Diphyllobothrium) also consume large quantities of vitamin B12 resulting in host deficiency (Nyberg et al., 1961). Vitamin B12 deficiency produces "ineffective erythropoiesis” in which bone marrow keeps producing cells, which are not very effective in transporting oxygen, thus stimulating hyperplasia (Aslinia et al., 2006).

Identification of hemolytic anemia on the basis of red blood cell osmotic fragility or identification of reduction of red blood cell half-life (Lanzkowsky, 1968) is not possible to for study in ancient bones. However, DNA studies may identify the responsible mutations for genetically-transmitted sources of hemolysis and the role of parasites may be amenable to DNA and ecological study.

\section{Accuracy of Dietary Maize Attributions: Isotope Implications}

Lee-Thorp (2008: p. 932) reported that there is "no isotope shift consistent with significant consumption of $\mathrm{C}_{4}$ maize until about AD 1000", in contrast to the claims based on occurrence of porotic hyperostosis by Angel (1978), Hill and Armelagos (1990), Stuart-Macadam and Kent (1992) and by Buikstra (Wilbur et al., 2008). This isotope observation should put to rest the mythology that porotic hyperostosis identifies nutritionally (maize)-related iron deficiency anemia (El-Najjar et al., 1975; Mensforth et al., 1978; Stuart-Macadam, 1989). According to Lee-Thorp (2008: p. 925), the advantage of stable isotope analysis is that it "reflects the foods actually eaten..., rather than a palimpsest of waste of uncertain duration that typically preserves only a tiny fraction of the original material and overlooks those organic remains with low survival rates”. Thus, maize was at most only a small component of diet prior to that time.

\section{Eliminating Mythology}

The misdirection related to the porotic hyperostosis-iron deficiency-maize speculation has for too long compromised the ability and opportunity of anthropology to contribute to understanding of ancient populations/civilizations. Greenberg (2009) discussed how citation distortions create unfounded authority, by establishing citation networks. Failure to incorporate "inconvenient" publications documents delayed promulgation of important ideas and corrections. A decade after Rothschild (2000) exposed the fallacy of primary iron deficiency-related porotic hyperostosis, Walker and colleagues (2009) acknowledged that porotic hyperostosis does not have the long ascribed (e.g., Stuart-Macadam, 1989) nutritional (e.g., maize "economies") implications. Could this be analogous to the Bruce effect in geladas (Roberts et al., 2012), another unpopular truism? Unfortunately, promulgation of the mythology has persisted, compromising anthropologic analyses for more than a decade. Despite this evidence, editors of major journals (e.g., American Journal of Physical Anthropology and the International Journal of Osteoarchaeology) have continued to publish articles predicated upon that erroneous premise (Dabbs, 2011; de la Cova, 2011; Meyer et al., 2011). Acceptance of those publications was based on the erroneous authoritative notion that presence of porotic hyperostosis identifies primary iron deficiency produced by maize ingestion, as repeatedly suggested by Buikstra (Wilbur et al., 2008) and others (Angel, 1978; Hill \& Armelagos, 1990; Scherer et al., 2007; Stuart-Macadam \& Kent, 1992; Wright \& Chew, 1999).

Extirpation of this mythology has been hindered by those who consider it a viewpoint. Gravity is not a viewpoint and neither is recognizing that primary iron deficiency does not produce porotic hyperostosis. Both represent scientifically validated, evidential observations. Lockyer et al. (2011) noted the difficulty weaning anthropologists away from this mythology. The current exposé should finally convince (assuming they pursue an intellectually honest review of the data) those still clinging to the mythology that porotic hyperostosis can be used as a measure of broad biologic processes like population migration and diffusion of genes, origin of agriculture and the relationship between economic transition and evolutionary processes, in addition to defining the health of populations (Angel, 1966; Bishop, 2011; Dabbs, 2011; De la Cova, 2011; El-Najjar et al., 1975; Lewis, 2011; Mensforth et al., 1978; Meyer et al., 2011; Scherer et al., 2007; Wilbur et al., 2008; Wright \& Chew, 1999).

The scholarly thing to do is to identify as compromised, all articles characterizing diet on the basis of porotic hyperostosis, in favor of reanalysis on the basis of what is actually known to produce the phenomenon. Misdirection has compromised use of a valuable observation-porotic hyperostosis. As Stuart-Macadam's 1989 attribution of porotic hyperostosis to maize has been falsified, perhaps it is now time to investigate the possibility of parasitic infections related to sanitary conditions and fecal-oral contamination? Perhaps now attention can be appropriately directed to exploration of genetic hemolytic anemias, hemoglobinopathies and parasitic infestations, which are known causes of porotic hyperostosis. Identifying parasite exposure and congenitally-transmitted hemolytic anemias could actually provide greater understanding of past cultures than the false suggestion of maize dietary implications ever did.

The challenge of what to do with articles subsequently invalidated or documented as compromised has been brewing in the natural and medical sciences for a few years now, and perhaps it is time that biological anthropology considers its stand on this issue. Should journal editors and/or reviewers be obligated to reject publication of articles whose premises have been documented as invalid and which selectively fail to cite pertinent literature? Doing nothing has allowed perpetration and promulgation of the myth that is the subject of this editorial. While this does not reflect positively on those who have succumbed and participated in allowing this mythology to persist, there is the opportunity for them to illustrate one of the best attributes of science: To admit that they had been misled and that their past perceptions on the subject were wrong. That would be in the finest tradition of science and identify within themselves the intellectual integrity that is the measure of a true scientist. 


\section{B. ROTHSCHILD}

\section{REFERENCES}

Agarwal, K. N., Har, N. D., \& Shah, M. M. (1970). Roentgenologic changes in iron deficiency anemia. American Journal of Roentgenology, 110, 635-637.

Angel, J. L. (1978). Porotic hyperostosis in the eastern Mediterranean. Medical College of Virginia Quarterly, 14, 10-16.

Angel, J. L. (1966). Porotic hyperostosis, anemias, malarias, and marshes in the prehistoric eastern Mediterranean. Science, 153, 760763. doi:10.1126/science. 153.3737 .760

Aslinia, F., Mazza, J. J., \& S. H. Yale (2006). Megaloblastic anemia and other causes of macrocytosis. Clinical Medicine \& Research, 4, 236-241. doi:10.3121/cmr.4.3.236

Bishop, K. (2011). Thule paleopathology: The health concerns of an artic lifestyle. Totem: The University of Western Ontario Journal of Anthropology, 19, 50-58.

Caffey, J. (1957). Cooley's anemia: A review of the roentgenographic findings in the skeleton. American Journal of Roentgenology, 78, 381-391.

Cavill, I. (2002). Erythropoiesis and iron. Best practice and research. Clinical Haematology, 15, 399-400.

Cavill, I., \& Ricketts, C. (1980). Human iron kinetics. In A. Jacobs, \& M. Worwood (Eds.), Iron in biochemistry and medicine II (pp. 573-604). London: Academic Press.

Dabbs, G. R. (2011). Health status among prehistoric Eskimos from Point Hope, Alaska. American Journal of Physical Anthropology, 146, 94-103. doi:10.1002/ajpa.21556

De la Cova, C. (2011). Race, health, and disease in 19th-century-born males. American Journal of Physical Anthropology, 144, 526-537. doi:10.1002/ajpa.21434

El-Najjar, M. Y., Lozoff, B., \& Ryan, D. J. (1975). The paleoepidemiology of porotic hyperostosis in the American Southwest. Radiological and ecological considerations. American Journal of Roentgenology, 125, 918-924.

Eng, L.-I. (1958). Chronic iron deficiency anaemia with bone changes resembling Cooley's anemia. Acta Hematologica, 19, 263-268. doi:10.1159/000205441

Fairbanks, V. F., \& Beutler, E. (1972). Erythrocyte disorders-Anemias related to disturbance of hemoglobin synthesis. In W. J. Williams, E. Beutler, A. J. Erslev, \& R. W. Rundles (Eds.), Hematology (pp. 305-326). New York: McGraw-Hill.

Goodhart, R. S., \& Shils, M. E. (1973). Modern nutrition in health and disease. Philadelphia: Lea \& Febiger.

Greenberg, S. A. (2009). How citation distortions create unfounded authority: Analysis of a citation network. British Medical Journal, 339, b2680. doi:10.1136/bmj.b2680

Grmek, M. D. (1989). Diseases in the ancient world. Baltimore: The Johns Hopkins University Press.

Hill, M. C., \& Armelagos, G. J. (1990). Porotic hyperostosis in past and present perspective. In J. E. Buikstra (Ed.), A life in science: Papers in honor of J. Lawrence angel, scientific papers No. 6 (pp. 52-63). Kampsville, IL: Center for American Archeology.

Jaffe, H. L. (1972). Metabolic, degenerative, and inflammatory diseases of bone and joints. Philadelphia: Lea \& Febiger.

Kaplan, E., \& Zuelzer, W. W. (1950). Erythrocyte survival studies in childhood: II. Studies in Mediterranean anemia. Journal of Laboratory Clinical Medicine, 36, 517-523.

Kattamis, C. A., Kyriazakou, M., \& Chaidas, S. (1969). Favism. Clinical and biochemical data. Journal of Medical Genetics, 6, 34-41. doi:10.1136/jmg.6.1.34

Lanzkowsky, P. (1968). Radiologic features of iron deficiency anemia. American Journal of Diseases of Children, 116, 16-29.

Lee-Thorp, J. A. (2008). On isotopes and old bones. Archaeometry, 50, 925-950. doi:10.1111/j.1475-4754.2008.00441.x

Lewis, R. (2011). Nutritional inference from paleopathological comparison of the Ootprint and Bonnell skeletal populations. Master Thesis, Lubbock: Texas Tech University.

Lockyer, N., Armstrong, I. \& Black, S. (2011). Bone pathology. In S. Black, \& E. Ferguson (Eds.), Forensic Anthropology 2000-2010 (pp. 237-255). Boca Raton: CRC Press, Taylor \& Francis. doi:10.1201/b10727-9

Mensforth, R. P., Lovejoy, C. O., Lallo, J. W., \& Armelagos, G. J. (1978). The role of constitutional factors, diet, and infectious disease in the etiology of porotic hyperostosis and periosteal reactions in prehistoric infants and children. Medical Anthropology, 1, 1-59. doi:10.1080/01459740.1978.9986939

Meyer, A., Keough, N., Nienaber, C. W., \& Steyn, M. (2011). A bioarchaeological investigation into the human remains discovered in the Chloorkop area, South Africa. International Journal of Osteoarchaeology. doi:10.1002/oa.1289

Nyberg, W., Gräsbeck, R., Saarni, M., \& von Bonsdorff, B. (1961). Serum vitamin $B_{12}$ levels and incidence of tapeworm anemia in a population heavily infected with Diphyllobothrium latum. American Journal of Clinical Nutrition, 9, 606-612.

Oxenham, M. F., \& Cavill, I. (2010). Porotic hyperostosis and cribra orbitalia: The erythropoietic response to iron-deficiency anemia. Anthropological Science, 118, 199-200. doi:10.1537/ase.100302

Resnick, D. (2002). Diagnosis of bone and joint disorders (2nd ed.). Philadelphia: Saunders.

Roberts, E. K., Lu, A., Bergman, T. J., \& Beehner, J. C. (2012). A Bruce effect in wild geladas. Science, 335, 1222-1225. doi:10.1126/science.1213600

Rothschild, B. (2000.). Porotic hyperostosis as a manifestation of deficiency? Chungara, Revista de Antropologia Chilena, 32, 85-87.

Rothschild, B. M., \& Martin, L. D. (2006). Skeletal impact of disease. Albuquerque: New Mexico Museum of Natural History.

Rothschild, B. M., Poteat, G. B., Williams, E., \& Crawford, W. L. (1994). Inflammatory sacroiliac joint pathology: Evaluation of radiologic assessment techniques. Clinical and Experimental Rheumatology, 12, 267-274.

Rothschild, B. M., Rühli, F., Sebes, J., Naples, V., \& Billard, M. (2005). Relationship between porotic hyperostosis and cribra orbitalia? Paleobios, 13, 4-7.

Scherer, A. K., Wright, L. E., \& Yoder, C. J. (2007). Bioarchaeological evidence for social and temporal differences in diet at Piedras Negras, Guatemala. Latin American Antiquity, 18, 85-104. doi: $10.2307 / 25063087$

Spodick, D. H. (1975). On experts and expertise. The effect of variability in observer performance. American Journal of Cardiology, 36, 592-596. doi:10.1016/0002-9149(75)90156-3

Stuart-Macadam, P. L. (1989). Nutritional deficiency diseases: A survey of scurvy, rickets and iron-deficiency anemia. In M. Y. Iscan, \& K. A. Kennedy (Eds.), Reconstruction of life from the skeleton (pp. 210-222). New York: Liss.

Stuart-Macadam, P., \& Kent S., (1992). Diet, demography and disease. New York: Gruyter.

Temperley, I. J., \& Sharp, A. A. (1962). The life span of erythrocytes in iron-deficiency anemia. Journal of Clinical Pathology, 15, 346-349. doi:10.1136/jcp.15.4.346

Von Endt, D. W., \& Ortner, D. J. (1982). Amino acid analysis of bone from a possible case of prehistoric iron deficiency from the American southwest. American Journal of Physical Anthropology, 59, 377385. doi:10.1002/ajpa.1330590407

Walker, P. L., Bathurst, R. R., Richman, R., Gjerdrum, T., \& Andrusko, V. A. (2009). The causes of porotic hyperostosis and cribra orbitalia: A reappraisal of the iron-deficiency-anemia hypothesis. American Journal of Physical Anthropology, 139, 109-125. doi:10.1002/ajpa.21031

Wilbur, A. K., Farnbach, A. W., Knudson, K. J., \& Buikstra, J. E. (2008). Diet, tuberculosis and the paleopathological record. Current Anthropology, 49, 963-991. doi:10.1086/592434

Wright, L. E., \& Chew, F. (1999). Porotic hyperostosis and paleoepidemiology: A forensic perspective on anemia among the Ancient Maya. American Anthropologist, 100, 924-939. doi:10.1525/aa.1998.100.4.924

Young, L. E., Izzo, M. J., \& Platzer, R. F. (1951). Hereditary spherocytosis. I. Hematologic and genetic features in 28 cases with particular reference to the osmotic and mechanical fragility of incubated erythrocytes. Blood, 6, 1073-1098. 